\title{
Feasibility analysis of an off-grid photovoltaic-battery energy system for a farm facility
}

\author{
Damilola Elizabeth Babatunde', Olubayo Moses Babatunde ${ }^{2}$, Micheal Uzoamaka Emezirinwune ${ }^{3}$, \\ Iheanacho Henry Denwigwe ${ }^{4}$, Taiwo Emmanuel Okharedia ${ }^{5}$, Oladele Julius Omodara ${ }^{6}$ \\ ${ }^{1,6}$ Department of Chemical Engineering, Covenant University, Nigeria \\ ${ }^{2,3,4,5}$ Department of Electrical Electronic Engineering, University of Lagos, Nigeria \\ ${ }^{5}$ Oaks and Pearl Engineering Partners, Nigeria \\ ${ }^{2} \mathrm{AB}$-OLUS and Associates, Nigeria
}

\begin{tabular}{l} 
Article Info \\
\hline Article history: \\
Received Apr 24, 2019 \\
Revised Dec 10, 2019 \\
Accepted Dec 16, 2019 \\
\hline Keywords: \\
Battery \\
Emission \\
Environmental sustainability \\
Photovoltaic \\
Renewable energy system \\
Techno-economic analysis
\end{tabular}

\begin{abstract}
Renewable energy plays a very important role in the improvement and promotion of environmental sustainability in agricultural-related activities. This paper evaluates the techno-economic and environmental benefits of deploying photovoltaic (PV)- battery systems in a livestock farmhouse. For the energy requirements of the farm to be determined, a walkthrough energy audit is conducted on the farmhouse. The farm selected for this study is located in southern Nigeria. The National Renewable Energy Laboratory's Hybrid Optimization Modeling for Electric Renewable (HOMER) software was adapted for the purpose of the techno-economic analysis. It is found that a standalone PV/battery-powered system in farmhouse applications has higher economic viability when compared to its diesel-powered counterparts in terms of total net present cost (TNPC). A saving of $48 \%$ is achievable over the TNPC and Cost of Energy with zero emissions. The results obtained show the numerous benefits of replacing diesel generators with renewable energy sources such as PV-battery systems in farming applications.
\end{abstract}

Copyright $\odot 2020$ Institute of Advanced Engineering and Science. All rights reserved.

\section{Corresponding Author:}

Damilola Elizabeth Babatunde,

Department of Chemical Engineering,

Covenant University,

PMB 1023, Ota, Ogun State, Nigeria.

Email: damilola.babatunde@covenantuniversity.edu.ng

\section{INTRODUCTION}

Access to energy which is clean, reliable and affordable (especially electricity) is essential to the sustainability of modern civilization $[1,2]$. This is because access to energy is vital and connected to many of the major opportunities and challenges experienced across the globe. Access to clean energy is essential to the creation of more jobs, mitigation of climate change as well as sustainable food production. Access to adequate and clean energy is therefore paramount to economic success as well as positive human health outputs. In order to achieve this, the United Nations has emphasized the indispensability of affordable and clean energy for all through item 7 on the sustainable development goals (SDG) [3]. Working towards achieving reliable, clean and affordable energy is essential because it has a connection with all other SDGs. As such, concentrating on widespread access to energy, energy conservation, energy efficiency and most especially, the increased penetration of renewable energy in the global energy mix would ensure sustainable societies and create resilience to environmental challenges such as climate change [4].

Currently, about 1 billion people lack access to electricity worldwide. Responsible for more than $50 \%$ of this population is Sub-Saharan Africa (SSA) [5, 6]. Consequently, homes and businesses are typically faced with unreliable electricity services. This scenario inflicts significant limitations on commercial activities, delivery of public services, and standard of living. Due to the low electrification rates 
in rural communities in Nigeria, many businesses located in rural communities are faced with adequate energy access challenges [7, 8]. For the alleviation of the effect of unreliable access to grid-connected electricity, many homes and business resorts to using captive diesel and gasoline generators [9]. This method of electrification has many challenges associated with it. Some of these include fluctuations in fuel pump prices, incessant scarcity of fuel products, exposure to toxic fumes, fire outbreaks, wear and tear [10-12], etc. Apart from these, the cost of energy is usually higher. This is because the cost involved in servicing and maintaining this form of electricity generation is high and consequently not profitable for many business owners. Hence, alternatives to fossil powered electricity generation is paramount.

In the recent past, the Nigerian government has pledged increased investments into the agricultural sector in Nigeria [13]. This is expected to boost the Gross Domestic Product (GDP) and create more employment opportunities among the youths. As a result of this, the number of entrepreneurs venturing into livestock farming is on the increase. Livestock farming requires electricity for its basic daily operation. Some of the energy-consuming activities on a livestock farm include water pumping, lighting, refrigerating, and other office activities. Traditionally, due to lack/inadequate electricity in Nigeria, livestock farms are either powered by gasoline or diesel generators. In order to avoid the bottlenecks and negative consequences exhibited by this means of energy production, the adoption of small-scale renewable energy technologies must be explored. Some of these technologies include Photovoltaic (PV), wind turbines, and biomass. As alternatives to fossil-fuelled generators, research into the use of renewable energy technologies for electricity production has been conducted and presented. However, the majority of renewable energy research efforts in SSA have only being directed towards meeting the basic energy needs for household applications [14-17]. Some of these researches have also been extended to meeting the energy needs of remote telecom base stations [18-20] and rural healthcare centres [6, 21-23]. Little research efforts have been extended to powering livestock farming in Nigeria.

The aim of this research is to elucidate the technical, cost and environmental viability and effectiveness of replacing captive diesel and gasoline generators with PV facility. This study, therefore, presents the techno-economic and environmental analysis of adopting a PV-battery energy system for powering a typical remote livestock farmhouse in Nigeria. This technology is selected due to its modularity and technological maturity in the Nigerian market. The results of these analyses would be effective in formulating informed policy for establishing off-grid livestock farms across Nigeria.

\section{RESEARCH METHOD}

The method used in this research is presented in this section as shown in Figure 1. The study was carried out between September 2017 and May 2018 in a typical remotely located livestock farm in Akinyele local government area of Oyo State, Nigeria. It method entails: calculation of daily water requirement, determination of total dynamic head (TDH) for pumping of water, estimation of hydraulic energy which is required daily to pump the water, extraction of available solar radiation of the site in terms of hours per day and calculation of the size of PV modules and batteries required based on the total load demand. The techno-economic analysis is implemented using Hybrid Optimization Modeling for Electric Renewable (HOMER). The details of the methodology are presented in the next sub-sections

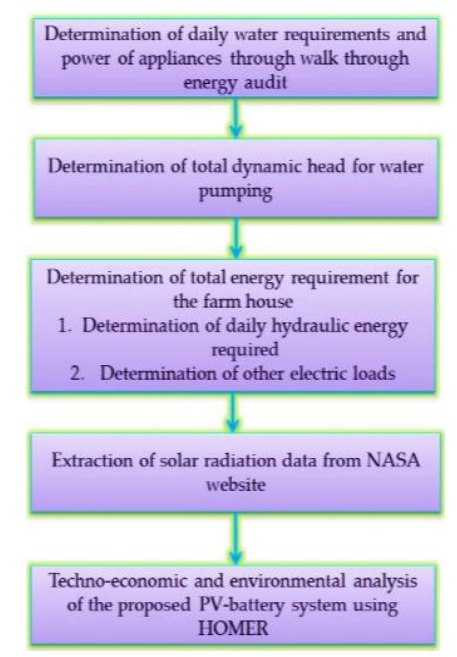

Figure 1. The methodology applied for the study 


\subsection{Walkthrough energy audit and determination of daily water requirement}

From the audit, it was identified that the farmhouse consists of 1 administrative office and 3 rooms accommodation for the farm attendants on night shifts. The total number of birds is 5000 while the farm breeds 250 goats. Based on these information, the daily water requirement of the farm was estimated as shown in Table 1 . The water requirements actually vary seasonally depending on the weather conditions (wet or dry). More water is used during dry weather conditions. The water requirement for the case study (based on the daily records from the farm) is given in Table 1. Water use on the farm is divided into three parts; the personnel on site, the birds and the goats on the farm.

Table 1. Estimated daily water requirement of the farm

\begin{tabular}{|c|c|c|c|}
\hline $\mathrm{S} / \mathrm{N}$ & Item & Quantity & Estimated water requirement (litre/day) \\
\hline 1 & Birds (chicken) & 5000 & 1705 \\
\hline 2 & Goats & 250 & 4732 \\
\hline 3 & Personnel/ Visitors & 8 & 1600 \\
\hline \multicolumn{3}{|c|}{ Total } & 8037 \\
\hline
\end{tabular}

\subsection{Determination of TDH}

The TDH (measured in meters) determines the effective pressure at which the pump must operate for the delivery of water. It consists of two parts; the vertical lift and the total frictional losses. The vertical lift is the addition of elevation, standing water level and drag down parameters. The frictional loss is the pressure that is required to overcome the friction in the pipes to the point of discharge. This is given as (1):

$$
T H D=T V_{l f}+T F_{l o s s}
$$

where $T V_{l f}$ is vertical lift and $T F_{\text {loss }}$ is total frictional losses

Step 3: determination of hydraulic energy required daily:

This is obtained by using (2).

$$
H_{e}=\rho \times V \times g \times T H D
$$

Based on calculations using (1) and (2), a $0.7 \mathrm{hp}$ motor is needed, but a $1 \mathrm{hp}$ motor is selected because of the possibility of getting the $0.7 \mathrm{hp}$ motor in the market and because of future expansion on the farm. This is equivalent to $746 \mathrm{~W}$.

\subsection{Determination of radiation data}

The location of the study receives a moderate solar radiance of approximately $6.16 \mathrm{kWh} / \mathrm{m} 2 /$ day and sunshine hour of about 6 hours daily. Figure 2 shows the monthly irradiance and a clearness index as obtained from the NASA website [24]. This data serves as metrological input to HOMER and it defines the operational capacity of the PV panels.

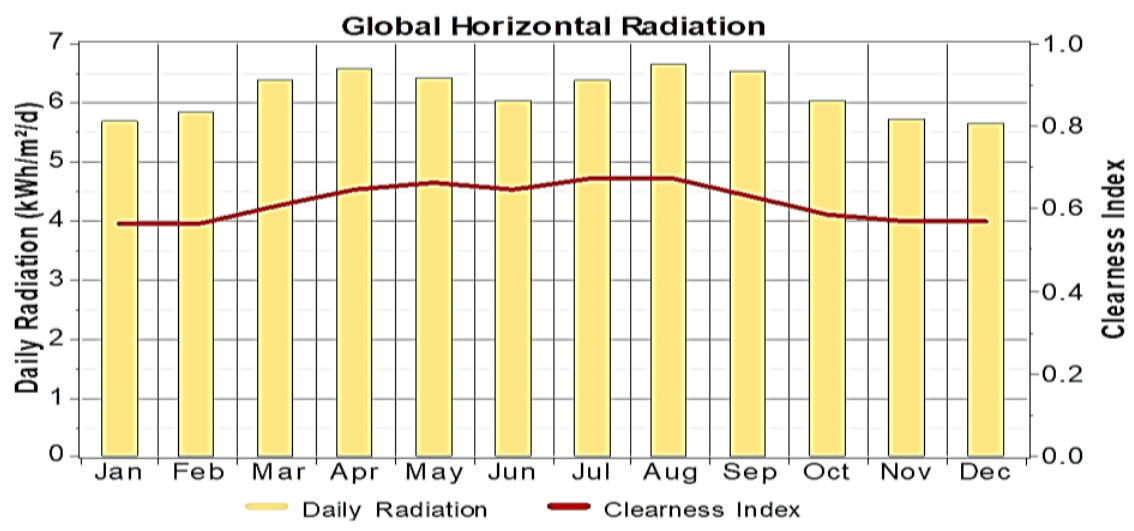

Figure 2. Monthly global irradiance on site 


\subsection{Techno-economic analysis}

The analysis that is used for choosing the PV-battery configuration is based on the optimization process. This is done using the National Renewable Energy Laboratory's Hybrid Optimization Modeling for Electric Renewable (HOMER) software. HOMER a design and optimization software for microgrids and distributed energy generation systems developed by the national renewable energy laboratory (NREL) was employed to determine the economic and technical viability of the proposed system [25]. It has the capacity to stimulate the system behaviour for 8760 hours of the year by making sure the system objective and constraints are satisfied. It compares the cost of different possible configurations and returns the system with the least TNPC as the most viable. Input parameters into the software are given in Table 2 . The equation used for computing the size of the PV, battery, the TNPC, and the LCOE is given in the next subsections.

Table 2. System component details [26]

\begin{tabular}{|c|c|c|c|}
\hline $\begin{array}{c}\text { Parameter description } \\
\text { PV }\end{array}$ & Value & $\begin{array}{r}\text { Parameter description } \\
\text { Battery }\end{array}$ & Value \\
\hline Rated Capacity & $1 \mathrm{~kW}$ & Rating & $4 \mathrm{~V}, 1900 \mathrm{Ah}$ \\
\hline Derating Factor & $80 \%$ & Round-trip efficiency & $85 \%$ \\
\hline Capital cost & $\$ 4.250 .00$ & Capital cost & $\$ 269.00$ \\
\hline Replacement cost & $\$ 4.200$ & Replacement cost & $\$ 260$ \\
\hline Operational life & 20 years & $\mathrm{O} \& \mathrm{M}$ cost & $\$ 5 / \mathrm{yr}$ \\
\hline $\begin{array}{l}\text { Ground reflectance } \\
\text { Converter }\end{array}$ & $20 \%$ & $\begin{array}{l}\text { Operational life } \\
\text { Diesel }\end{array}$ & 4 years \\
\hline Rated power & $1 \mathrm{~kW}$ & Rated power & $1 \mathrm{Kw}$ \\
\hline Efficiency & $90 \%$ & Capital cost & $\$ 280$ \\
\hline Capital cost & $\$ 621.80$ & Replacement cost & $\$ 280$ \\
\hline Replacement cost & $\$ 569$ & $\mathrm{O} \& \mathrm{M}$ cost & $0.5 \$ / \mathrm{hr}$ \\
\hline $\mathrm{O} \& \mathrm{M}$ cost & $\$ 3 / \mathrm{yr}$ & Operational life & 15000hours \\
\hline Operational life & 15 years & Minimum load ratio & $30 \%$ \\
\hline
\end{tabular}

\subsubsection{PV system}

The energy available for the PV array to deliver at a specific location is given by (3) [27].

$$
\operatorname{Epv}(t)=H(t) \times B \times s \times \eta_{p v}
$$

where: $\mathrm{H}(\mathrm{t})$ is hourly insolation $\left(\mathrm{kWh} / \mathrm{m}^{2}\right)$, B is the surface area of the PV module $\left(\mathrm{m}^{2}\right)$, $\mathrm{s}$ is the factor of penetration, $\eta_{\mathrm{PV}}$ is the PV panel efficiency. The efficiency of the PV generator is given as [27]:

$$
\eta_{\mathrm{PV}}=\eta_{\mathrm{r}} \eta_{\mathrm{cp}}\left[1-a\left(\mathrm{~T}_{\mathrm{d}}-\mathrm{T}_{\mathrm{dref}}\right)\right]
$$

where $\eta_{\mathrm{r}}$ is the efficiency of the reference module, $\eta_{\mathrm{cp}}$ is the efficiency for power conditioning, $a$ is the temperature coefficient for the efficiency of the generator, $\mathrm{T}_{\mathrm{dref}}$ is the temperature of the reference cell $\left({ }^{\circ} \mathrm{C}\right), \mathrm{T}_{\mathrm{d}}$ is the temperature of the cell $\left({ }^{\circ} \mathrm{C}\right)$ which is obtained from the temperature of the surrounding $\mathrm{T}_{\mathrm{s}}\left({ }^{\circ} \mathrm{C}\right)$ and the sun's radiation $(\mathrm{Ra})$ as follows:

$$
\mathrm{T}_{\mathrm{d}}=\mathrm{T}_{\mathrm{s}}+\left(\frac{\mathrm{NTOC}-20}{800}\right) \mathrm{Ra}
$$

\subsubsection{Battery capacity}

HOMER uses (6) to calculate the storage capacity of the battery [28]:

$$
B_{S c}=\frac{D L \times B A_{d}}{\eta_{B a} \times D o B D \times V_{s n}}
$$

where DL, $B A_{d}, \eta_{B a}$, DoBD, and $V_{s n}$ are the demands of the load, days of battery autonomy, round-trip efficiency of the battery, depth of battery discharge and the system's nominal voltage respectively.

\subsubsection{Economic analysis}

a. Total net present cost (TNPC)

HOMER uses (7) to estimate the Total Net Present Cost (TNPC) [6].

$$
T N P C=\frac{T C_{a n}}{F_{c r}\left(i, X_{p r o j}\right)}
$$


$T C_{a n n}$ represents the total cost obtained annually, $F_{c r}$ represents the capital recovery factor, $i$ represents the interest rate $(\%)$, and $X_{\text {proj }}$ is the lifetime of the project. For this work, the interest rate used is $12 \%$, while the lifetime of the project is 25 years.

b. Levelised cost of energy (LCOE)

The levelised cost of energy $\left(L_{\mathrm{COE}}\right)$ is computed using (8) [6].

$$
L C O E=\frac{T C G E_{a n n}}{T D E M}
$$

where $T C G E_{\text {ann }}$ Represents the total cost of annual electricity generation while TDEM is the total electricity demand met by the source of electricity generation.

\subsection{Configuration of the proposed energy system}

The system arrangement for the PV only powered system and the diesel generator only is shown in Figure 3. The proposed energy system comprises of solar panel, batteries, converter, charge controllers and its accessories. The primary load is attached to the AC bus while the pumping machine is attached to the DC bus. The battery serves as backup storage to ensure an uninterrupted supply of power while the converter ensures energy flow between the water pump and PV as well as the battery charging. The technical and economic details of the proposed PV-battery energy system are presented in Table 2. These information serves as input data for the software.

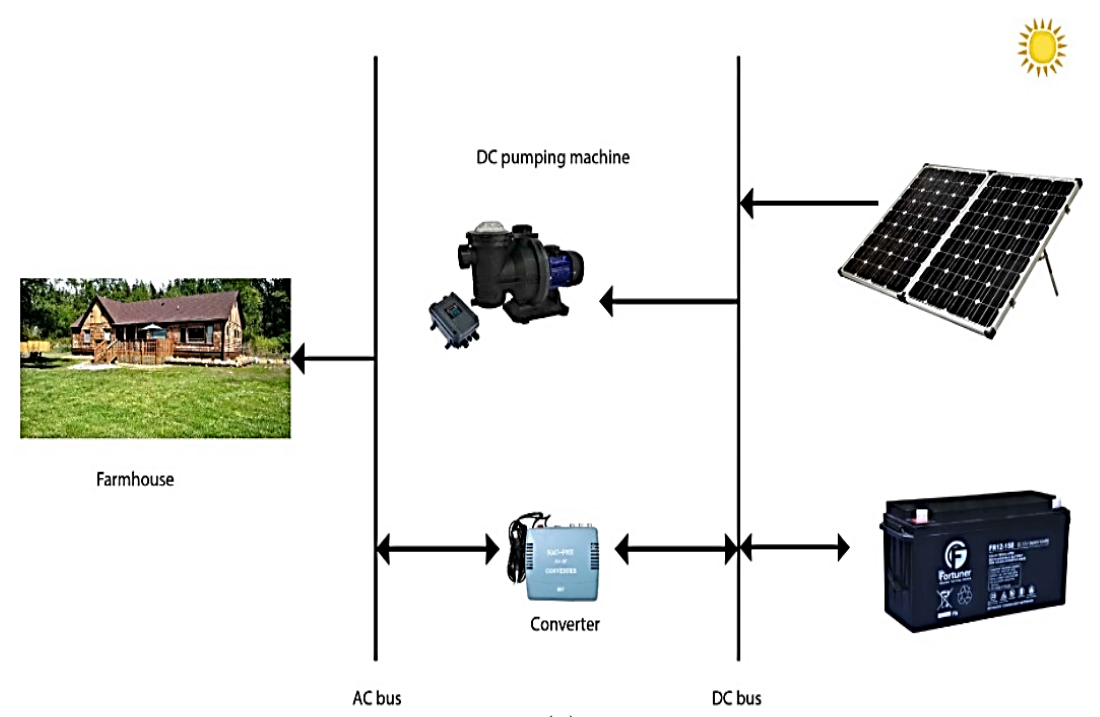

(a)

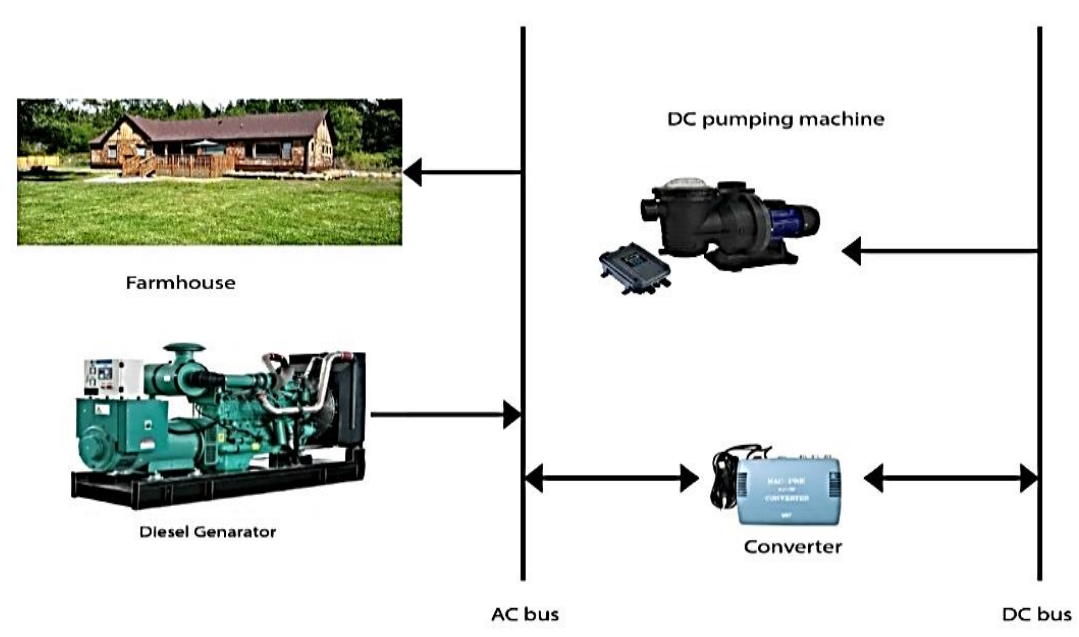

(b)

Figure 3. Schematic diagram of simulations in HOMER: (a) PV only (b) diesel only 


\section{RESULTS AND ANALYSIS}

\subsection{Farmhouse load profile}

The breakdown of electricity use by appliances on the farmhouse (apart from water pumping) is presented in Table 3. Figures $4 \mathrm{a}$ and $4 \mathrm{~b}$ present the load profiles of the farm (primary and deferrable). The total primary daily energy demand is estimated as $6.37 \mathrm{Wh} /$ day with the peak demand $(0.58 \mathrm{~kW})$ occurring between 20:00 hours and 21:00 hours and the least $(0.15 \mathrm{~kW})$ occurring between 08:00-09:00 hours as shown in Figure 4a. Furthermore, according to Figure 4b, the highest deferrable energy demand is attributed to the month of January and February (about 800W).

Table 3. Power ratings and hours of use of other equipment

\begin{tabular}{lcccc}
\hline \multicolumn{1}{c}{ Load } & Power Rating $(\mathrm{W})$ & Hour/day & Number & $\mathrm{kWh}$ \\
\hline CFL & 15 & 12 & 10 & 1.8 \\
Fan & 65 & 15 & 2 & 1.95 \\
TV & 150 & 6 & 1 & 0.9 \\
Refigirator & 150 & 8 & 1 & 1.2 \\
Computer & 65 & 8 & 1 & 0.52 \\
Total daily demand $(\mathrm{kWh})$ & & & & 6.37 \\
\hline
\end{tabular}

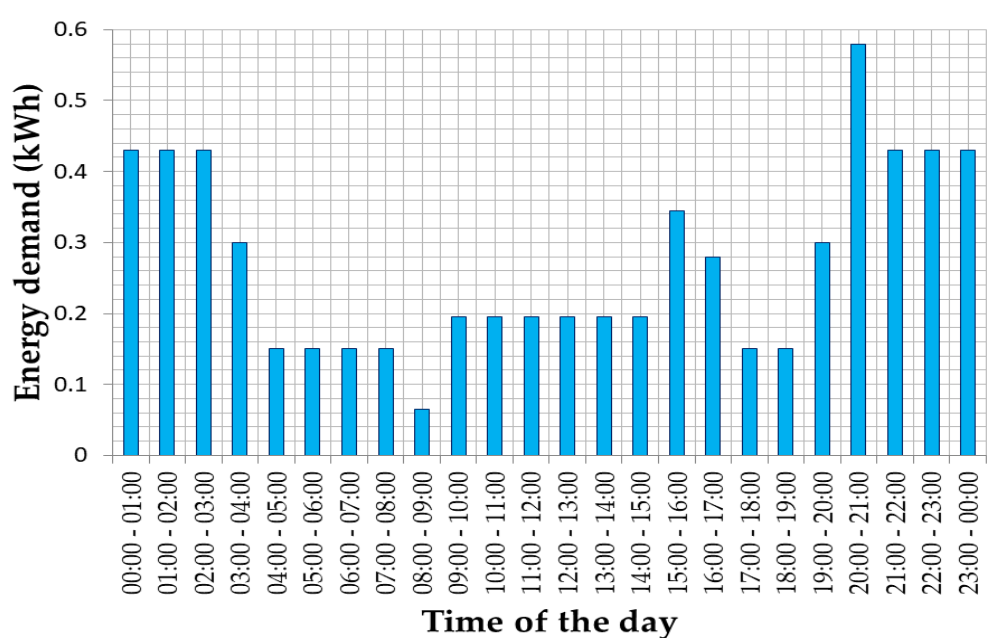

(a)

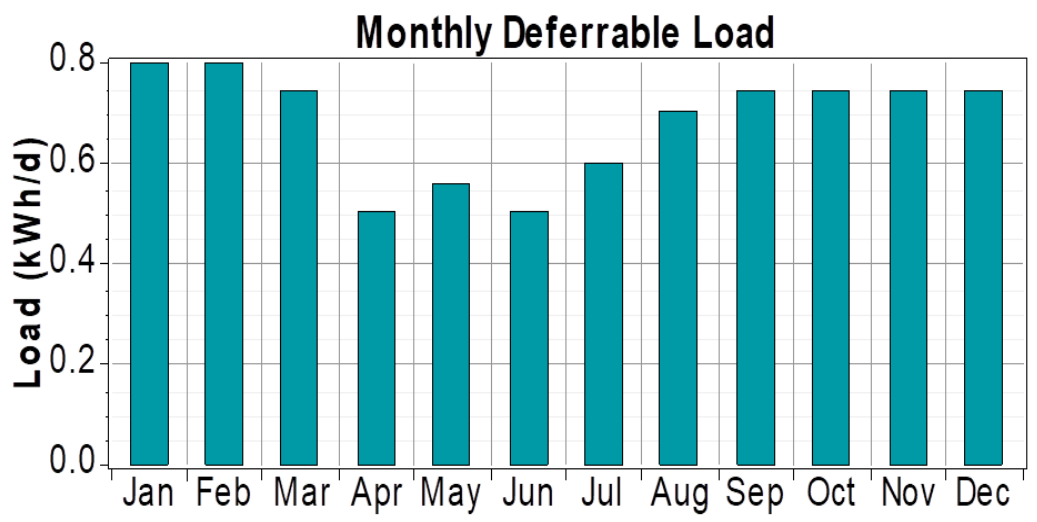

(b)

Figure 4. (a) Primary daily load profile (b) Deferrable monthly load profile

\subsection{Energy system configuration}

HOMER implemented an hourly time series simulation of possible energy system nomenclature. The output from this incus: annual electricity production, component size, economic (TNPC, LCOE), and the quantity of GHG emitted. The optimal configuration was selected based on the least TNPC. Table 4 presents the details of the results obtained. The best energy alternative consists of a $3 \mathrm{~kW}$ PV array, 
4 batteries, and $1 \mathrm{~kW}$ converter and with $100 \%$ renewable fraction. The TNPC and LCOE for the diesel generator-only option of generation over the lifetime of the project are higher by $48 \%$ in contrast to the PV-only system. The results of the emissions resulting from the use of the diesel generator are given in Table 4. The emission quantified include carbon dioxide $\left(\mathrm{CO}_{2}\right)$, carbon monoxide (CO), unburned hydrocarbons (UHs), particulate matters (PMs), sulfur dioxide $\left(\mathrm{SO}_{2}\right)$, Nitrogen oxides $(\mathrm{NOx})$.

The standalone "diesel-only" generator emitted $3897 \mathrm{~kg}$ of $\mathrm{CO}_{2}$ annually while the PV system did not generate any air pollutants as shown in Table 4. Presented in Figure 5 is the cost comparison for the two energy alternatives. The capital cost of the PV-battery energy system is $\$ 14448$ while the other costs are: operating cost- $\$ 248$, TNPC is $\$ 17616$, and LCOE is $\$ 0.535$. For the diesel generator, the initial cost is $\$ 591$, the operating cost is $\$ 2370$, TNPC is $\$ 41855$, and LCOE is 0.934 . The cash flow summary with regards to the different cost components for the proposed system is given in Figure 6. It shows that the initial capital had the highest NPC $(\$ 14,500)$ followed by replacement cost $(\$ 5000)$, the operation cost contributed $\$ 1000$ while the NPC of the salvage cost is negative. Since the proposed system does not have a captive generator, the value for the NPC of the fuel is zero. Based on the result presented in Table 5, in terms of the system components, the PV returned the highest cost $(\$ 14,881)$. This is followed by the battery $(\$ 1,902)$, while the converter had the least $(\$ 833)$.

Table 4. Performance evaluation of diesel only and PV powered system configuration

\begin{tabular}{|c|c|c|c|}
\hline \multicolumn{4}{|c|}{ Technical } \\
\hline Parameter & Diesel generator & PV powered & Unit \\
\hline PV Panel size & - & 3 & \\
\hline Generator size & 1 & - & $\mathrm{kW}$ \\
\hline Power electronic converter size & 0.5 & 1 & \\
\hline Batteries & - & 4 & No \\
\hline \multicolumn{4}{|c|}{ Economic } \\
\hline Initial capital cost & 591 & 14448 & $\$$ \\
\hline Operating cost & 2370 & 248 & $\$$ \\
\hline TNPC & 41855 & 17616 & $\$$ \\
\hline LCOE & 0.934 & 0.535 & $\$ / \mathrm{kWh}$ \\
\hline \multicolumn{4}{|c|}{ Greenhouse gas Emissions } \\
\hline $\mathrm{CO}_{2}$ & 3.897 & - & \multirow{6}{*}{$\mathrm{kg} / \mathrm{yr}$} \\
\hline $\mathrm{CO}$ & 9.62 & - & \\
\hline UHs & 1.07 & - & \\
\hline PMs & 0.725 & - & \\
\hline $\mathrm{SO}_{2}$ & 7.83 & - & \\
\hline NOx & 85.8 & - & \\
\hline \multicolumn{4}{|c|}{ Electricity production } \\
\hline Annual electricity Production & 3.145 & 5.395 & $\mathrm{kWhr} / \mathrm{yr}$ \\
\hline excess electricity & 526 & 2.136 & $\mathrm{kWhr} / \mathrm{yr}$ \\
\hline Unmet Load & 0 & 0.00000041 & $\mathrm{kWhr} / \mathrm{yr}$ \\
\hline Shortage capacity & 0.00543 & 0.00543 & $\mathrm{kWhr} / \mathrm{yr}$ \\
\hline Renewable fraction & 0 & 100 & $\%$ \\
\hline
\end{tabular}

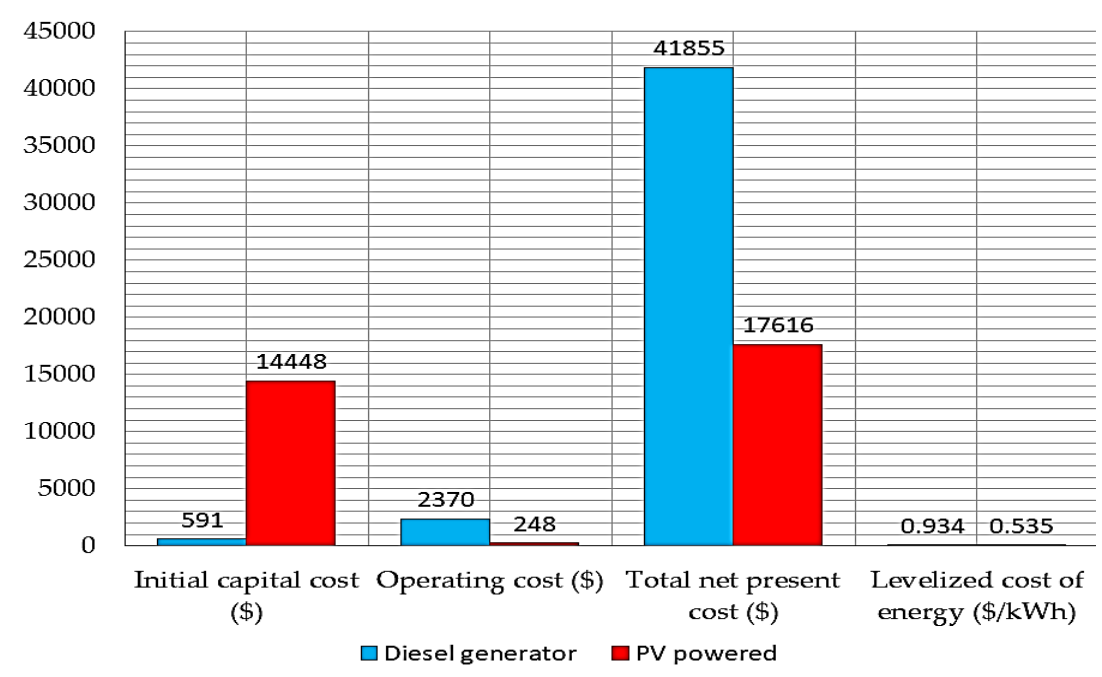

Figure 5. Economic comparison of diesel-only and PV system 


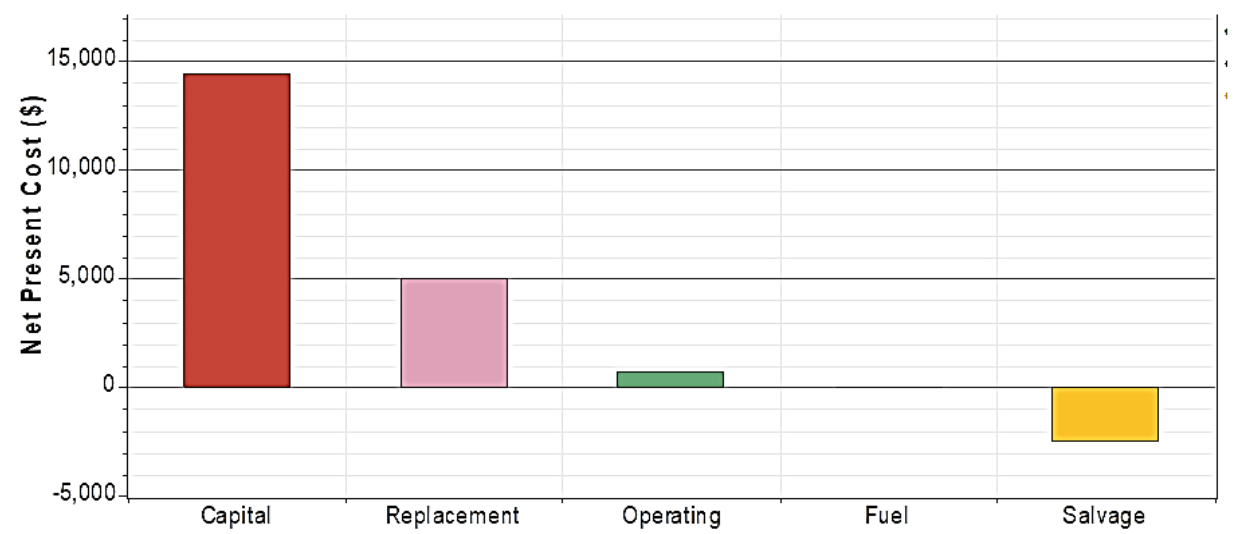

Figure 6. Cash flow summary

Table 5. Breakdown of TNPC based on components' cost

\begin{tabular}{lccccc}
\hline \multicolumn{1}{c}{ Item } & Capital (\$) & Replacement (\$) & O\&M (\$) & Salvage $(\$)$ & Total (\$) \\
\hline PV & 12.750 & 3.976 & 384 & -2.228 & 14.881 \\
Battery & 1.076 & 800 & 256 & -230 & 1.902 \\
Converter & 622 & 259 & 0 & -48 & 833 \\
System & 14.448 & 5.035 & 639 & -2.506 & 17.616 \\
\hline
\end{tabular}

The possibility of replacing diesel generators with a PV-battery system for electricity production on a farmhouse has been explored in this study. Results from the analysis show that the PV-battery energy system is viable with higher initial investment capital but lower operating cost, LCOE, and TNPC when compared to a diesel generator. An emission reduction was also achieved by replacing diesel generator with PV-battery system. The results of this study are consistent with the ones reported by Babatunde et al. [21], Akinyele [28], and Ohijeagbon et al. [29]. Meanwhile, Akinbulire et al. [14], Olatomiwa et al. [30], Ayodele and Ogunjuyigbe [19] and Adaramola et al. [31] gave a contrary result by stating that the inclusion of a diesel generator with the PV-battery system could mitigate the effect of intermittency of solar radiation resource. To the best of our knowledge, this is one of the pioneer techno-economic feasibility studies directed at adopting PV-battery system for livestock farms in Nigeria. Future research efforts could be geared towards methods that are flexible and cost-effective by which these technologies can be selected by users. Also, the inclusion biomass and wind turbine can be explored to see its effects on the system configuration and the cost of energy. Although the analysis of the study is case-specific, its methodology can be adopted globally.

\section{CONCLUSION}

This study elucidates the technical, economic and environmental viability of powering a farmhouse with a PV-battery energy system as against a diesel generator. This study discovered that the adoption of the PV-battery for powering a poultry farm is technically, economically and environmentally feasible and better than diesel only. It shows that the cost of energy while using the proposed energy system is lower and this, in turn, will lower the energy expenditure. This will consequently increase the overall profit of the business as the expense of energy decreases. Emissions to the atmosphere are also eliminated. This will help business owners and policymakers in making an informed decision as regards the deployment of PVbattery energy systems for agricultural-related purposes.

\section{ACKNOWLEDGEMENTS}

The authors thank the Managements of Covenant University and the University of Lagos for the conducive environment provided during the conduct of this research. The authors also acknowledge the technical and financial support given by AB-Olus and associates towards the site visits. The article publication support given by Covenant University is appreciated by the authors. 


\section{REFERENCES}

[1] Babatunde, O. M., Adedoja, O. S., Babatunde, D. E., \& Denwigwe, I. H., “Off-grid hybrid renewable energy system for rural healthcare centers: A case study in Nigeria," Energy Science \& Engineering, vol. 7, no. 3, pp. 676-693, 2019.

[2] D. E. Babatunde, O. M. Babatunde, T. O. Akinbulire, and P. O. Oluseyi, "Hybrid energy systems model with the inclusion of energy efficiency measures: A rural application perspective," Int. J. Energy Econ. Policy, vol. 8, no. 4, pp. 310-323, 2018.

[3] C. G. Monyei, K. E. H. Jenkins, S. Viriri, and A. O. Adewumi, "Policy discussion for sustainable integrated electricity expansion in South Africa," Energy Policy, vol. 120, pp. 132-143, 2018.

[4] J. E. J. Streatfeild, "Low Electricity Supply in Sub-Saharan Africa: Causes, Implications, and Remedies," J. Int'l Com. Econ., pp. 1-16, 2018.

[5] C. G. Monyei and A. O. Adewumi, "Demand Side Management potentials for mitigating energy poverty in South Africa," Energy Policy, vol. 111, pp. 298-311, 2017.

[6] L. Olatomiwa, R. Blanchard, S. Mekhilef, and D. Akinyele, "Hybrid renewable energy supply for rural healthcare facilities: An approach to quality healthcare delivery," Sustain. Energy Technol. Assessments, vol. 30, pp. 121-138, 2018.

[7] U. Akpan, M. Essien, and S. Isihak, "The impact of rural electrification on rural micro-enterprises in Niger Delta, Nigeria," Energy Sustain. Dev., vol. 17, no. 5, pp. 504-509, 2013.

[8] F. F. Nchuchuwe and K. D. Adejuwon, "The challenges of agriculture and rural development in Africa: the case of Nigeria," Int. J. Acad. Res. Progress. Educ. Dev., vol. 1, no. 3, pp. 45-61, 2012.

[9] M. P. Blimpo and M. Cosgrove-Davies, "Electricity Access in Sub-Saharan Africa: Uptake, Reliability, and Complementary Factors for Economic Impact,” World Bank Publications, 2019.

[10] M. S. Adaramola, S. S. Paul, and O. M. Oyewola, "Assessment of decentralized hybrid PV solar-diesel power system for applications in Northern part of Nigeria," Energy Sustain. Dev., vol. 19, pp. 72-82, 2014.

[11] S. O. Oyedepo, "Towards achieving energy for sustainable development in Nigeria," Renew. Sustain. energy Rev., vol. 34, pp. 255-272, 2014.

[12] S. O. Oyedepo, "Energy in perspective of sustainable development in Nigeria," Sustain. Energy, vol. 1, no. 2, pp. 14-25, 2013.

[13] B. M. Inusa, P. C. Daniel, D. F. Dayagal, and N. S. Chiya, "Nigerian economic growth and recovery: Role of agriculture," Int J Econ Manag Sci, vol. 7, no. 2, pp. 1-5, 2018.

[14] T. O. Akinbulire, P. O. Oluseyi, and O. M. Babatunde, "Techno-economic and environmental evaluation of demand side management techniques for rural electrification in Ibadan, Nigeria," Int. J. Energy Environ. Eng., vol. 5, pp. 375-385, 2014.

[15] M. S. Adaramola, "Viability of grid-connected solar PV energy system in Jos, Nigeria," Int. J. Electr. Power Energy Syst., vol. 61, pp. 64-69, 2014.

[16] D. O. Akinyele, "Distributed Photovoltaic Power Generation for Energy- Poor Households: The Nigerian Perspective," 2013 IEEE PES Asia-Pacific Power and Energy Engineering Conference (APPEEC) 2013, 2013.

[17] D. Akinyele, "Analysis of photovoltaic mini-grid systems for remote locations: A techno-economic approach," Int. J. Energy Res., vol. 42, pp. 1363-1380, 2017.

[18] L. J. Olatomiwa, S. Mekhilef, and A. S. N. Huda, "Optimal sizing of hybrid energy system for a remote telecom tower: A case study in Nigeria," in Energy Conversion (CENCON), 2014 IEEE Conference on, 2014.

[19] S. O. Ogunjuyigbe and T. R. Ayodele, "Techno-economic analysis of stand-alone hybrid energy system for Nigerian telecom industry," Int. J. Renew. Energy Technol., vol. 7, no. 2, 2016.

[20] M. S. Okundamiya, J. O. Emagbetere, and E. A. Ogujor, "Assessment of renewable energy technology and a case of sustainable energy in mobile telecommunication sector," Sci. World J., vol. 2014, no. 4, pp. 1-13, 2014.

[21] O. Babatunde, D. Akinyele, T. Akinbulire, and P. Oluseyi, "Evaluation of a grid-independent solar photovoltaic system for primary health centres (PHCs) in developing countries," Renew. Energy Focus, vol. 24, pp. 16-27, 2018.

[22] D. E. Ighravwe, B. OM, O. S. Adedoja, and T. E. Okharedia, "Evaluation and Selection of Hybrid Renewable Energy Systems for Healthcare Centres In Rural Areas: A Techno-economic Approach," in 2018 IEEE 7th International Conference on Adaptive Science \& Technology (ICAST), 2018.

[23] L. Olatomiwa and S. Mekhilef, "Techno-economic feasibility of hybrid renewable energy system for rural health centre (RHC): The wayward for quality health delivery," in 2015 IEEE Conference on Energy Conversion, CENCON 2015, 2016.

[24] NASA, "NASA Surface meteorology and Solar Energy-Location," 2018.

[25] T. Lambert, P. Gilman, and P. Lilienthal, "Micropower System Modeling with Homer," in Integration of Alternative Sources of Energy, pp. 379-418, 2006.

[26] O. M. Babatunde, P. O. Oluseyi, T. O. Akinbulire, H. I. Denwigwe, and T. J. Akin-Adeniyi, "The Role of DemandSide Management in Carbon Footprint Reduction in Modern Energy Services for Rural Health Clinics," in Environmental Carbon Footprints, Elsevier, pp. 317-363, 2018.

[27] D. O. Akinyele and R. K. Rayudu, "Comprehensive techno-economic and environmental impact study of a localised photovoltaic power system (PPS) for off-grid communities," Energy Convers. Manag., vol. 124, pp. 266-279, 2016.

[28] D. Akinyele, "Techno-economic design and performance analysis of nanogrid systems for households in energypoor villages," Sustain. Cities Soc., vol. 34, pp. 335-357, 2017.

[29] O. D. Ohijeagbon and O. O. Ajayi, "Solar regime and LVOE of PV embedded generation systems in Nigeria," 
Renew. Energy, vol. 78, no. C, pp. 226-235, 2015.

[30] L. Olatomiwa, S. Mekhilef, A. S. N. Huda, and K. Sanusi, "Techno-economic analysis of hybrid PV--diesel-battery and PV--wind--diesel--battery power systems for mobile BTS: the way forward for rural development," Energy Sci. Eng., vol. 3, no. 4, pp. 271-285, 2015.

[31] M. S. Adaramola, M. Agelin-Chaab, and S. S. Paul, "Analysis of hybrid energy systems for application in southern Ghana,” Energy Convers. Manag., vol. 88, pp. 284-295, 2014.

\section{BIOGRAPHIES OF AUTHORS}
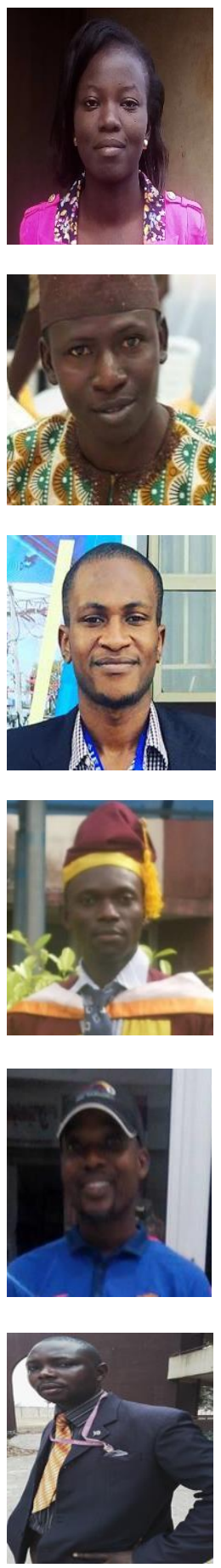

Engr. Okharedia Taiwo Emmanuel is a graduate of the University of Lagos where he obtained his B. Sc (Computer Engineering) and M.sc (Electrical/Electronic Engineering) with specialization in Electrical Power Engineering.

Engr. Omodara Oladele Julius is a member of the Nigerian Society of Engineers (MNSE) and a registered Engineer (COREN). He obtained Bachelor of Engineering (B.ENG) in Chemical Engineering from the University of Port Harcourt, Rivers State. He bagged Master of Science in Chemical Engineering, from the University of Lagos. He also a holder of Master of Engineering degree in Petroleum Engineering, from Covenant University. He has over Fourteen years work experience in different but relevant fields. His work experiences amongst others are; in academics, in the area of quality control and assurance in process industry, pipeline \& wellhead inspection and maintenance in oil field and gas, paint formulation, production and technology. At present, he is the senior technologist in-charge of Pilot Plant/Unit Operations Laboratory of the Chemical Engineering Department, Covenant University. 